УДК 631.3

(C) Голота Б.М., Р.В. Кірчук, к.т.н., Тарасюк В.В., к.т.н.

Луцький національний технічний університет

\title{
МОДЕЛЮВАННЯ РОБОТИ КОТКА ДЛЯ ПОДРІБНЕННЯ РОСЛИНННИХ РЕШТОК ТА ОБГРУНТУВАННЯ ЙОГО ПAPAMETPIB
}

У статті наведено огляд конструкиій та виконано аналіз процесу подрібнення рослинних решток в полі задля збільшення вмісту органіки у трунті. Представлено модель роботи котка та запропоновано методику встановлення його параметрів.

ГРУНТ, КОТОК, РОСЛИННІ ЗАЛИШКИ, СТЕБЛО, НІЖ, МОДЕЛЬ

Постановка проблеми. Створення екологічно вирощування ня рослин завжди актуальна, але техногенне забруднення родючих грунтів мінеральними добривами негативно позначається на якості сільськогосподарської продукції. Широке застосування пестицидів створило i специфічні проблеми. Це набуття бур'янами, шкідниками та збудниками хвороб стійкості до них $[1,2]$.

Новітні технології у галузі рослинництва потребують суттєвих змін і до систем машин. Так, запровадження мінімальних і нульових технологій обробітку грунту, прямого висіву, передбачають виконання нових технологічних операцій. До таких відноситься підготовка поверхні поля до традиційного, мінімального обробітку чи прямого висіву, тобто мульчування або подрібнення рослинних решток велико-стеблових культур соняшнику, кукурудзи та інших[1,2]. 
Аналіз останніх досліджень і публікацій. В нашій країні мало уваги приділяється створенню сільськогосподарських машин такого типу, аби їх робота була спрямована на поліпшення стану родючого шару грунту природним шляхом, як варіант - створення на поверхні поля шару із подрібнених рослинних решток із частковим їхнім загортанням. Науковці ствержують, що такий підхід допоможе захистити мікрофлору грунту і дасть змогу не тільки стабілізувати, а й через певний час підвищити вміст гумусу [1-4].

Для подрібнення рослинних решток здебільшого використовують імпортні і вітчизняні машини, оснащені активними робочими органами із приводом від ВВП, горизонтальним та вертикальним розташуванням осей обертання. Аналогічні машини на ринку України представлено компаніями-виробниками: «Уманьферммаш», «Білоцерків-МАЗ», «Агрореммаш», «Бердянськсільмаш». Однак, вони мають досить суттєвий недолік не подрібнюють рослинні рештки, які лежать на поверхні поля, особливо в міжряддях, та потребують значних витрат енергії на привод робочих органів [1-5].

Мета дослідження - дослідити особливості використання механізмів подрібнення рослинних решток в полі, створити модель їх роботи для числового експерименту та обгрунтувати кінематичні і геометричні параметри робочих органів.

Результати дослідження. Подрібнювані рослинних решток на поверхні поля після збирання врожаю $є$ машинами, використання яких широко запроваджується в цивілізованих країнах, як невід'ємна операція в загальній грунтозахисній, енергозберігаючій технології виробництва продукції рослинництва. В Україні аналогічною до подрібнення є операція дискування, в більшості, важкими дисковими боронами, забороненими до використання в США, Канаді взагалі, як знаряддя, що знищують структуру грунтів. Корисливе ж ставлення до грунтів людьми, які їх експлуатують і не дбають про їх майбутнє, гальмує запровадження сучасних технологій в галузі рослинництва. Тому подрібнювані рослинних решток залишаються для нашого сільськогосподарського виробника незрозумілими i рідкісними представниками даного сімейства машин на українських полях. А користь від даних машин беззаперечна, саме за їх допомогою можна підготувати стан поля для подальшого обробітку за будь якою технологією без шкідливого для грунтів переущільнення, а головне - перерозпушування і руйнування структури, відновлення якої потребує багатьох десятиліть [2]. 
Робочим органом котків $є$ циліндрична поверхня, якою він діє на грунт. При перекочуванні котка по поверхні поля часточки грунту переміщуються в горизонтальному і вертикальному напрямках, описуючи певну траєкторію. Характер i форма траєкторії залежать переважно від параметрів котка, радіального навантаження на коток, грунтових умов i місця знаходження часточки в шарі грунту піднімаються вгору, а потім опускаються до певного рівня.

Коткування полягає у вертикальному переміщенні часточок грунту. Поздовжня деформація грунту значною мірою залежить від діаметра котка. За однакової глибині колієутворення поздовжня деформація грунту збільшується зі зменшенням діаметра котка. Застосування котків із малим діаметром призводить до небажаних результатів.

Основними параметрами котка $\epsilon$ діаметр i ширина (довжина). Вибираючи діаметр котка, слід ураховувати поздовжню деформацію грунту. Цього досягають за умови, що кут $\alpha$ (рис. 1) обхвату котка грунтом не перевищуватиме $20^{\circ}$. При цьому грунтовий валик перед котком має незначний розмір [6].

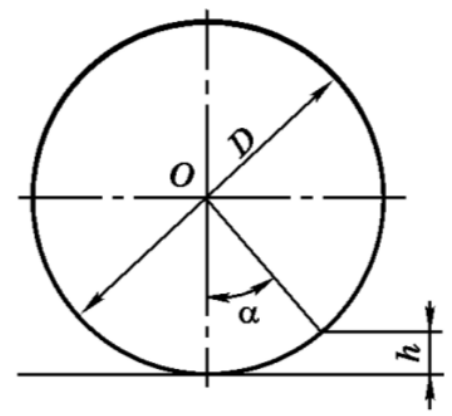

Рис. 1 - Схема до визначення діаметра котка

3 рис. 1 видно, що

$$
\cos \alpha=\frac{D-2 h}{D}=1-\frac{2 h}{D},
$$

де $D$ - діаметр котка;

$h$ - глибина колії котка.

Із залежності (1) визначається діаметр котка:

$$
D \geq \frac{2}{1-\cos \alpha} .
$$


Задаючи глибину колії котка i кут обхвату, можна визначити допустимий мінімальний діаметр котка. Ширину захвату котка вибирають залежно від умов пристосування його до рельєфу поля. Для рівнинних умов ширина котка становить близько 2 м, а для гірського рельєфу та пересічених полів - не більше ніж 1 м.

Процес роботи кільчасто-шпорових, кільчасто-зубчастих, кільчастих і борончастих котків дещо відмінний. Верхній шар грунту вони залишають розпушеним, а нижній - ущільнюють так само, як це робить гладенький коток.

Таким чином, з (2) можна отримати:

$$
D=\frac{1-\cos \alpha}{2 h}=\frac{1-\cos 20^{\circ}}{2(0,07 \ldots 0,10)}=0,43 \text { мм }
$$

Зважаючи на існуючі конструкції котків-подрібнювачів діаметр кладе $\mathrm{D}=470 \mathrm{Mм}$, а його ширина рівна $2 \mathrm{~m}$. Висота зуба, як правило, 7-10 см.

Значні зміни фізико-механічних властивостей грунту під час коткування ускладнюють точний розрахунок зусилля на перекочування котка. Дослідники [2,6,7], виходячи 3 тих чи інших передумов, виводять різні формули для визначення зусилля на перекочування котка. Зусилля на перекочування колеса чи котка вперше визначив Грандвуале, а пізніше підтвердив В.П. Горячкін. Згідно з цими розробками зусилля $P$ на перекочування гладенького котка визначають за формулою:

$$
P=0,86 \sqrt[3]{\frac{G^{4}}{q_{0} B D^{2}}},
$$

де $G$ - сила ваги котка, $\mathrm{H}$;

$B$ - ширина захвату котка, см;

D - діаметр котка, см;

$q_{0}$-коефіцієнт об'ємної деформації грунту, Н/см3 $(0,3<\mathrm{q} 0<0,5)$.

Зусилля перекочування негладенького котка дещо більше:

$$
P=0,86 \cdot k \cdot \sqrt[3]{\frac{G^{4}}{q_{0} B D^{2}}},
$$

де $k=1,0 \ldots 1,3$ - коефіцієнт, що враховує додатковий опір від деформації грунту, яку здійснюють негладенькі елементи котка. 
Для суцільних кільчастих котків $\mathrm{k}=1,1 \ldots 1,2$, для комбінованих - $\mathrm{k}=1,1 \ldots 1,3$, для котків, у яких кільця розміщені 3 деякою відстанню між ними, $\mathrm{k}=1,0$. Глибина колії визначає ступінь руйнування структури грунту.

На рис.2. показана конструкції машини, а на рис.3. - типи котків, що набули широкого використання у господарствах.

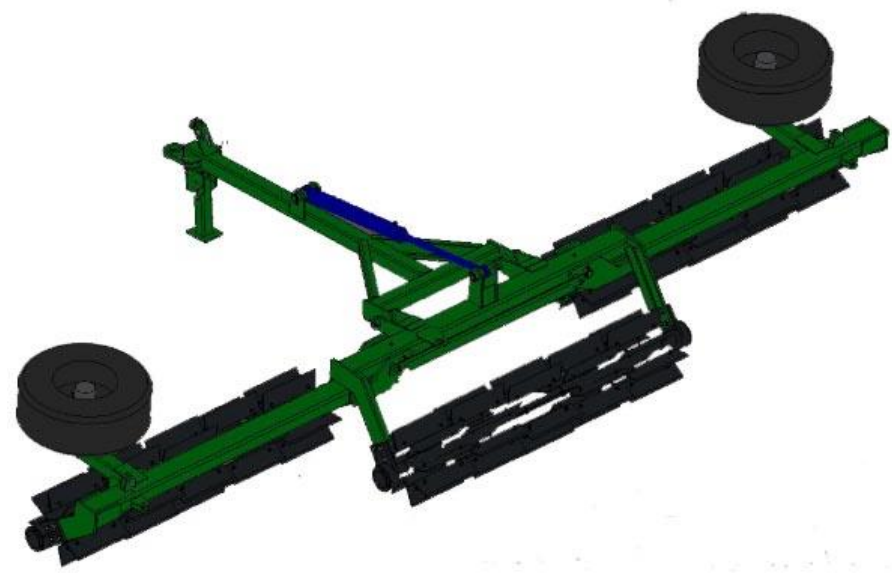

Рис.2. - Загальний вигляд подрібнювача рослинних решток у робочому положенні

Відповідно загальне зусилля для трьох котків складе:

$$
P_{3}=3 P=3 \cdot 7,5 \cdot 10^{3}=22,5 \cdot 10^{3} \mathrm{H} \text {. }
$$

Так як робоча швидкість агрегату становить до 12 км/год то споживана потужність складатиме $N=P_{3} v$.

Виходячи з розрахунків та рекомендацій слід застосовувати для агрегатування подрібнювача рослинних решток трактор потужністю не менше 80к.с. (клас тяги 2).

Робочі органи котка-подрібнювача рослинних решток здійснюють складний рух: поступальний з агрегатом і обертальний біля осі барабана. Розглянемо траєкторію руху робочого органу, коли агрегат переміщається прямолінійно і рівномірно зі швидкістю $v$ (рис. 4). 


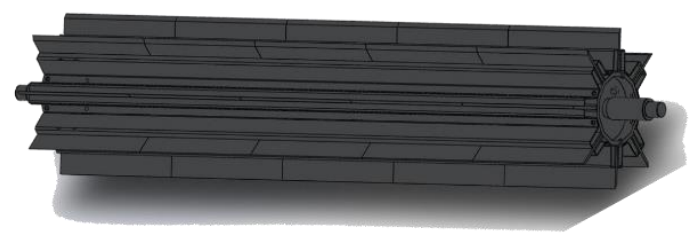

a)

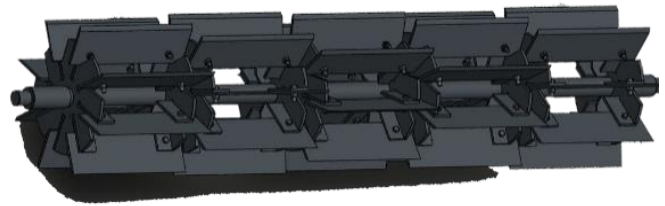

б)

Рис.3 - Варіанти котків для подрібнювача рослинних решток: а- водоналивний, б - каркасний

На рисунку показано, що $r$ - радіус котка. Відстань від центра обертання котка до т. М $\epsilon$ сумою радіуса $r$ та висоти зуба $h$ . Обертання котка характеризується кутом повороту котка $\varphi$.

Траєкторія руху вершини зуба, що показана на рис.4, носить назву «трохоїда». Вона описується параметричними рівняннями типу:

$$
\left.\begin{array}{l}
x=r \varphi-(r+h) \sin \varphi \\
y=r-(r+h) \cos \varphi
\end{array}\right\}
$$

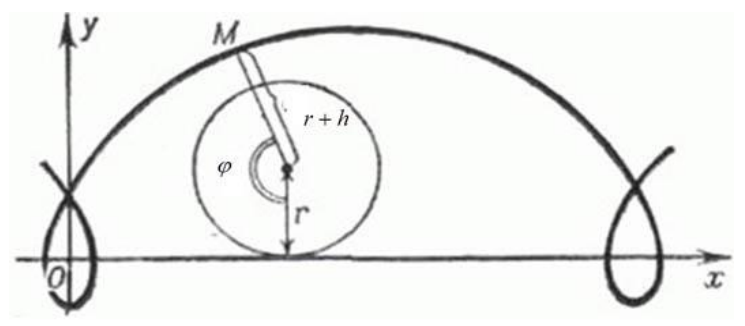

Рис.4 - Схема руху робочих органів котка-подрібнювача 
У свою чергу кут $\varphi$ може бути виражений через відомі кінематичні параметри агрегату, а саме:

$$
\varphi=\omega \tau=\frac{v}{r} \tau,
$$

де $\tau$ - системний час, с.

Для розрахунку рівнянь та побудови моделі руху т. М було використано систему динамічного моделювання Model Vision. На рис. 5 та рис.6 показано вигляд системи та отриманий графічний результат.

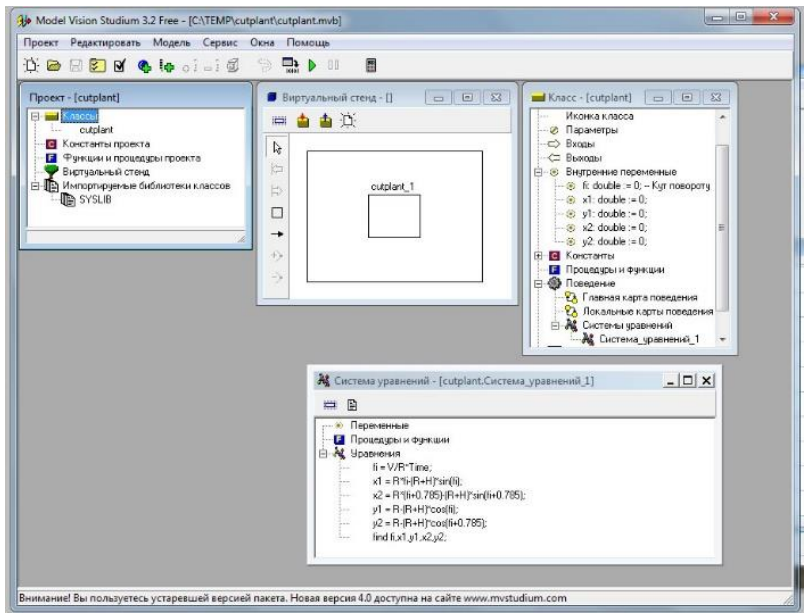

Рис.5 - Загальний вигляд системи моделювання Model Vision

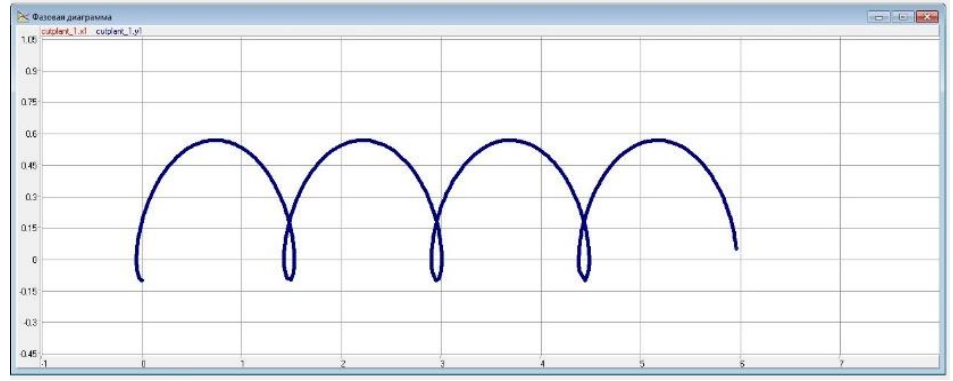

Рис.6 - Траєкторія руху т. М подрібнювача рослинних решток 
Як видно $з$ рис. 6 відстань між двома сусідніми точками контакту вершини ножа і грунту складає 1,5 м. Для дотримання агротехнічних умов величини подрібнення рослинних решток слід встановити кілька рядів таких ножів на котку.

Згідно агротехнічних вимог величина стебел всіх культур бур'янів та іншої рослинності повинні бути подрібнені на величину не більше 25 см $[2,6]$. Тому кількість рядів зубів на котку становить $n=\frac{1,5}{0,25}=6$ шт. Приймаємо із запасом $n=8$. Тоді, максимальні розміри рослинних решток складуть не більше $\ell=1,5 / 8=0,19$ м.

Висновоки. Останнім часом, кількість органічних добрив, що вносяться у грунт в нашій країні, зменшилась приблизно у 7 разів. Тому рослини забирають із грунту значно більше поживних речовин, ніж вноситься. В результаті щорічні втрати гумусу 3 грунтів за розрахунками вчених-грунтознавців становлять близько 20млн. тонн. Якщо негайно не запровадити заходи зі збереження гумусу, то українські чорноземи перетворяться на малородючі землі.

Досвід провідних аграрних країн показує: реальним шляхом зменшення втрат гумусу в грунтах i покращення їх родючості, який не потребує великих фінансових витрат, $є$ підвищення ефективності використання пожнивних решток, що залишаються на полях після збирання урожаю. Пожнивні залишки (стерня, стебла бур'янів, валки соломи) подрібнюються спеціальними машинами - подрібнювачами. Вони не тільки скошують пожнивні рештки, а й подрібнюють на частинки довжиною до 15 см і рівномірно розподіляють по полю.

Після такого подрібнення рослинні рештки надійно покриваються шаром грунту, навіть при його обробітку дисковими знаряддями, які зараз широко використовуються аграріями. Як результат, забезпечується розкладання рослинних залишків в анаеробних умовах і ефективне збагачення грунту органікою.

На рис.7 показано вигляд поля до і після обробітку подрібнювачам рослинних решток. 


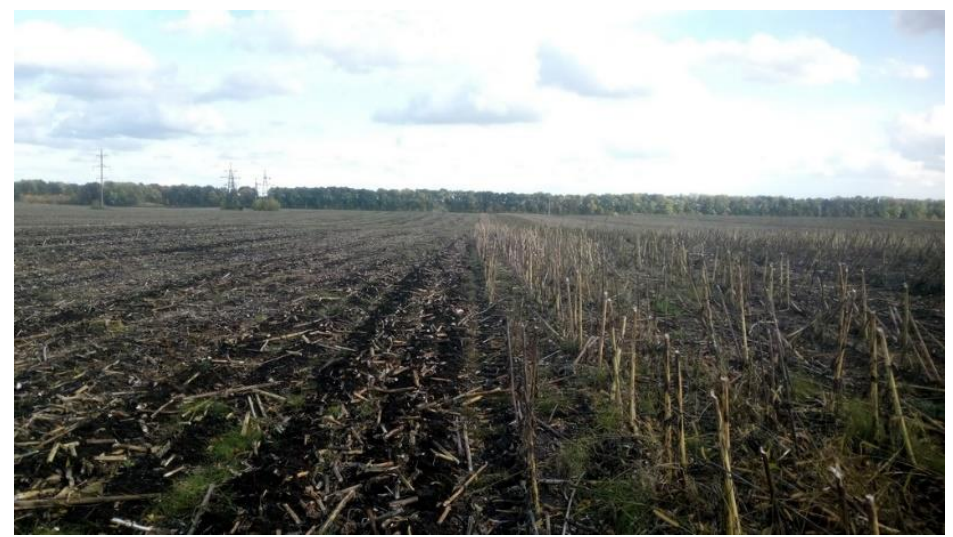

Рис.7 - Вигляд поля до і після обробітку подрібнювачам рослинних решток

Запропонована методика дає можливість розрахувати параметри котка подрібнювача рослинних решток. Така машина добре себе зарекомендувала при: подрібненні рослинних залишків кукурудзи, соняшнику, ріпаку та інших культур; часткової обробки верхнього шару грунту, розрізання стебел; вирівнювання і рівномірний розподіл залишків по поверхні поля; сприяє накопиченню грунтової вологи; закладення органічних і мінеральних добрив, прискорення процесу розкладання рослинних залишків.

\section{Література \\ 1. Обладнання для подрібнення рослинних решток} [Електронний ресурс]/ В. Сало, Д. Богатирьов//Пропозиція Головний журнал 3 питань агробізнесу- Режим доступу до журн.: https://propozitsiya.com/ua/obladnannya-dlya-podribnennya-roslynnyhreshtok.

2. Машини для обробітку грунту та внесення добрив. Навчальний посібник для студентів агротехнічних спеціальностей./ Сало В.М., Лещенко С.М., Лузан П.Г., Мачок Ю.В., Богатирьов Д.В.-Х.: Мачулін, 2016.-244 с.:іл.

3. Способи обробітку рослинних решток [Електронний ресурс]/М.Д.Іванчук//Агроном - Режим доступу до журн.: https://agronom.com.ua/sposoby-obrobitku-roslynnyh-reshtok/

4. Мульчувач Мютінг. Подрібнення рослинних решток [Електронний ресурс]//MilkUA.info - Режим доступу до журн.: 
http://milkua.info/uk/post/mulcuvac-muting-podribnenna-roslinnihrestok

5. Myths and Facts about Residue Breakdown [Електронний pecypc]/ Mahdi Al-Kaisi//Integrated Crop Management News - April 4, 2014- Режим доступу до журн.: https://crops.extension.iastate.edu/cropnews/ 2014/04/myths-and-factsabout-residue-breakdown

6. Сільськогосподарські машини. Основи теорії та розрахунку: Підручник/ Д.Г.Войтюк, В.М.Барановський, В.М.Булгаков та ін.; за ред. Д.Г.Войтюка.-К.: Вища освіта, 2005.-464с.:іл.

7. Конструкція, розрахунок i виробництво сільськогосподарських машин. Кон-спект лекцій для студентів спеціальності „Машини та обладнання сільськогосподарського виробництва" машинобудівного факультету денної та заочної форм навчання - Цизь I.Є.-Луцьк : ЛНТУ, 2008.-140с. 